\title{
DIE BETEKENIS VAN TÉLEIOS EN SY DERIVATE \\ IN DIE HEBREERBRIEF
}

\author{
DS. G. M. M. PELSER*
}

A. Motivering van die ondersoek.

Die vraag na die betekenis van téleois en sy derivate in die Hebreërbrief word hoofsaaklik op drie verskillende wyses beantwoord.

(i) In die eerste plek is, veral deur vroeëre uitleggers, die begrip in kulties-sakrale betekenis gesien d.w.s. dat in die aanwending van die begrip slegs in formele sin die wyding tot priester tot uitdrukking kom sowel as die deelhê van die aanbidder aan die kultus. Hiermee samehangend is die opvatting dat hierin ' $n$ parallel te vind is met die inisiasie van die mustés in die Misteriegodsdienste.

(ii) Ten tweede, en deur die meeste uitleggers, word die betekenis van sedelike perfektheid aan hierdie begrip geheg. Hiervolgens gaan dit dan om in indiwidualistiese moralisering t.o.v. die gelowige in die godsdiens.

(iii) In die derde plek bestaan die opvatting van wyding of toerusting tot ' $n$ amp of opdrag en die uitvoering daarvan totdat die eindpunt of die voltooiing bereik is. Met ander woorde hier is alle moralisme uitgesluit en word alle klem gelê op die volbrenging van die opdrag of die ten einde voering van ' $n$ saak.

Ons sal met hierdie ondersoek hierdie antwoorde of opvattinge moet ondersoek om vas te stel watter die mees aanvaarbare is, en dus die beste uitdrukking kan gee van waarom dit in die heilswerk van Jesus Christus gaan, wat die sentrale tema van die Hebreërbrief is.

\section{B. Buitebybelse gebruik}

Delling ${ }^{1}$ ) het aangetoon dat in die buite-Bybelse gebruik van hierdie begrip veral die volgende betekenisse na vore gekom het:

(a) Volkome, sonder gebrek, bv. die offerdier en dan ook volkome in omvang.

* Skripsie voorgelê ter vervulling van 'n deel van die vereistes vir die D.D.eksamen aan die Universiteit van Pretoria.

1) D. G. Delling. Theologisches Wörterbuch zum Neuen Testament, Band Vili, lieferung 2, Stuttgart 1965, bls. $68-78$. 
(b) Volkome in die Philoniese sin van volkomene, voleindigde.

(c) Om tot die télos gebring te wees m.a.w. verwerklik.

(d) As attribuut van ' $n$ godheid bv. magtig, werkend.

(e) In biologiese sin bv. opgegroei, volgroeid, ryp.

(f) In die sin van ingewyd, geīnisieer.

In die filosofie het dit gegaan om die gehele menswees en die volle areté. Vir Plato is hierdie téleos - - ánthrôpos hy wat die fronésis en vaste, ware beskouingsinsig en filosofiese kennis het. Vir Aristoteles gaan dit uitdruklik om die teleia aretê wat dààr bestaan waar ' $n$ etiese keuring metafroné seôs geskied. Die stoa sê téleios is net hy wat alle sedelike waardighede (aretas) besit en teleia is ' $n$ daad slegs wanneer dit alle aretai voldoende besit m.a.w. almal daarin saamwerk. Vir Philo gaan dit om die volkomene teenoor die onvolkomene. ' $n$ Volkome goeie is elpis as die verwagting van die agatha God is, to teleion - - kai prós alétheian agathon. Godwelgevallige lewe is die teleôtaton t.o.v. regverdig- en volkome wees en die toppunt van die hoogste eudaimonia.

In die Qumran - literatuur betrek tamim sig op die een wat vlekkeloos is aan gees en liggaam. Net om te wandel volgens die insettinge van die gemeente wat openbaringe van die Thora is, is 'n vlekkelose lewenswandel moontlik. Vlekkeloos wandel beteken om nie na links of regs of te wyk nie en nie een van die woorde van God te oortree nie.

\section{LXX en die Nuwe Testament.}

(a) In die LXX beteken die woord ongedeeld, volkome, geheel. So bv. die hart wat onverdeeld moet wees prôs kûrion d.w.s. sonder vreemde godsdiens 1 Kron. $28: 9$ van die reslose wegvoering. Jer. $13: 19$. Ook liggaamlike gebrekloosheid soos van die paaslam Ex. 12:5.

(b) In die N.T. kom in die Mt. Evangelie en Katolieke briewe die betekenis geheel na vore. In die Paulusbriewe bv. 1 Kor. 13:10 is téleios in teenstelling met ek merous. In Kol. 1: 28 gaan dit vir Paulus om die volwasse mens.

Die werkwoorde teleô enteleioô kom in die N.T. veral voor betekenis van verwerklik, deurvoer bv. t.o.v. die werk van Christus (Joh. $4: 34,5: 36,17: 4$ ). Anders as in die aktiewe gebruik beteken die perfektum passief bv. in $1 \mathrm{Joh}$. geheel, volkome. Die volkome wees van die dissipels in Joh. 17:23 bestaan uit die: .Ek in hulle en $U$ in $M y^{\prime \prime}$ Joh. 17:21. Omdat Paulus nog nie die oorwinningsprys behaal het nie, is hy nog nie volmaak nie (Phil. 
$3: 12$ ), want hy het nog nie die doel bereik nie. (Phil. $3: 14$ ). Die liefde is die band van die volmaaktheid omdat dit die gemeente tot 'n geheel saambind.

Die werkwoorde teleô en teleioo kom in die N.T. veral voor in die betekenis deurvoer, voltrek. By teleioô tree egter sterker die gedagte van geheelheid, totaliteit na vore.

\section{Eksegese van die betrokke uitsprake in die Hebreërsbrief.}

T.w.v. groter duidelikheid sal ons eers die Skrifgedeeltes in die Hebreërbrief ondersoek waarin die werkwoord teleioun voorkom. Daarna sal ons aandag skenk aan diè wat met teleios verband het. Waar die werkwoord teleioun gebruik word gaan dit in die eerste plek om die vraag wie die subjek en wie die objek is van die voltrekking van die teleiôsis. Hieruit blyk dat in hoofstuk 2:10, 5:9 en 7:28 God die Handelende is wat dit aan Christus voltrek. In $10: 14$ en $12: 2$ is Christus die Voltrekker aan die gelowiges en in $12: 23$ is God die Handelende aan die regverdiges.

(1) God die subjek.

\section{$2: 10$}

Hier sê die skrywer dat dit God gepas het eprepen gar autôi om die Bewerker van hulle saligheid, (sotéria) hulle eskatologiese heil, deur lydinge te voleindig. (dia pathématôn teleiôsai). Dit is dus nie in teenspraak met die eer en waardigheid van God, dat Jesus as Bewerker van die sôtêria die lydensweg gaan nie. Inteendeel, daar is geen ander weg van verlossing nie as die weg van vernedering en lyding van die Seun van God. Deur hierdie lydinge het God die teleiôsis aan die Seun voltrek.

\section{$5: 9$}

Hier skets die outeur hoedat Jesus Christus wat Hoëpriester geword het volgens die orde van Melchisedek, gehoorsaamheid geleer het uit wat $\mathrm{Hy}$ gely het. Nadat $\mathrm{Hy}$ deur God voleindig is (teleiôthèis) het $\mathrm{Hy}$ die $\mathrm{Be}-$ werker geword van ewige saligheid vir diè wat Hom gehoorsaam is. Al was Hy die Seun het dit Hom nie gevrywaar van lyding nie.

\section{$7: 28$}

Teenoor die wet wat mense met swakhede as hoëpriester aangestel het, word hier die woord van eedswering gestel waardeur die Seun aangestel is, tot in ewigheid voleindig (teteleiômenon). 
(i) teleioun in Kulties-sakrale betekenis.

Die vraag wat hier beantwoord moet word is of die teleiôsis wat aan Christus voltrek is, gesien moet word as 'n parallel van die inisiasie van die mustés in die misterie-godsdiens òf as 'n heilige konsekrasie in gnostiese $\sin$. Michel ${ }^{2}$ ) wys daarop dat die afleiding vanuit die misteries vroeër geliefd was (Plato. Phaidros) maar sedert die navorsing van A.M. Festugière en M.J. Lagrange het uitleggers vir hierdie afleiding versigtig geword. Dikwels het die Joodse Hellenisme self onderskei tussen die kultiese teleiôsis van die O.T. en die teletai van die misteries (Philo De uit. Mos II 149). Eksegete het ook onderskei tussen die ontvangers van wyding wat met die participium tetelesmenoi, teloumenoi gekarakteriseer is en die Bybelse spreekwyse van teleioi (bv. E. Allo en C. Spieq). Die betekenis van ingewyd in die sin van die taalgebruik van die misteries word egter in die N.T. nòg aangewend nòg veronderstel. ${ }^{3}$ )

Onseker en te verwerp bly ook die oostersgnostiese samehang wat $E$. Käsemann ${ }^{4}$ ) aangedui het. Hy gaan van die Mandeīese mite van die opvaart uit waarvan die doel die voleinding is. Die oermens-verlosser word geprys vir die weg wat hy gewys het uit die "huis van die lewe".

Debelius ${ }^{5}$ ) bv. sien hierdie tekste uit 'n suiwere kultiessakrale oogpunt en staan sterk teen enige morele kwaliteite van die werkwoord teleioun. „Man wird also teleiôsis als vollendende Weihe erklären dürfen und teleioun auf die Erteilung dieser Weihe beziehen." Die inisiasie van Christus sien hy dan nie as 'n serie van kultiese dade nie, maar as èèn allesvoldoende inwyding in die ewige hemelse heiligdom wat Sy verhoging is. Archégos vertaal hy met "Führer" en dink dan aan die verlosser van die Anthropos mite. Die vernedering en verhoging van Christus is dan „eines grossartigen Erde und Himmel umfassenden Kultmysteriums", waardeur Hy die weg na die hemelse heiligdom berei en waarin Hy gekonsekreer is deur Sy dood. Dit is dan Sy voleindiging.

2) O. Michel, Der Brief an die Hebräer, Göttingen 1966, bls. 226.

3) D. G. Delling, a.w. bls. 78.

4) E. Käsemann, aangehaal by 0 . Michel, a.w., bls. 226.

5) O. Debelius, aangehaal by P. J. du Plessis, Téleios the idea of perfection 
E. Riggenbach ${ }^{6}$ ) het betoog dat die begrip "wyding" onmoontlik is. Dit gaan hier juis om ' $n$ teenstelling met die onvolkomenheid van hulle wat tot priesters in die Ou Verbond gewy is. Christus het dan die doel bereik wat die priesters nie kon bereik nie.

Dit blyk dat die hellenisties-sakrale taalgebruik van teleioun baie oud is. ') Alhoewel die gnostiese interpretasie hier verwerp moet word, kan nie ontken word nie, dat hier tog invloed uitgeoefen moes gewees het deur die gebruik van teleioun t.o.v. die priesterwyding in die LXX. ${ }^{8}$ )

Die wyding van die priester is in die O.T. 'n „vul van sy hande met offergawes". (Ex. 29:9; Lev. 4:5, $8: 33$ millê). Die LXX gee hierdie Hebreeuse uitdrukking weer met empimplanai, pléroun, maar ook met teleioun tas cheiras. Hier toon dit dat in die Hellenisme teleioun gaandeweg die betekenis van, "tot priester wy of instel", verkry het. " $)$ In Lev. 21: 10 word teleioun selfs sonder tas cheiras gebruik.

Dit is egter 'n vraag of die taalgebruik van Hebreërs deurgaans in hierdie kultiese betekenis aangedui moet word. Hierdie parallelisme kan egter nie sondermeer verwerp word nie, veral as in aanmerking geneem word dat die skrywer, soos duidelik blyk uit die sitate in die Hebreërbrief, baie vertroud met die LXX moes gewees het.

Agter die feit dat Christus Hoëpriester is volgens die orde van Melchisedek lê die implikasie dat Hy tot hierdie diens gewy is ${ }^{10}$ ) en toegerus is ${ }^{11}$ ) as Bewerker van die saligheid. God het Hom vaardig gemaak om priesterlik handelend voor Hom te tree en wel deur lyding. ${ }^{12}$ ) Die woordgebruik dui meer op 'n momentele wyding as op die moontlikheid dat Hy trapsgewyse tot die diens gewy is. ${ }^{13}$ ) In

10) P. J. du Plessis, a.w., b/s. 214.

11) O. Cullmann, Die Christologie des Neuen Testaments, Tübingen 1957, bls. 91.

12) D. G. Delling, a.w., bls. 84.

13) P. J. du Plessis, a.w., bls. 214. 
$2: 10$ en $5: 9$ word die momentele van hierdie wyding aangedui terwyl 7:28 die voortdurende effektiwiteit daarvan na vore bring.

Die sterk beklemtoning van die tydelike karakter van die O.T. priesterskap, laat dink dat die aanstelling van Christus 'n preëksistensiële moes wees. Hy het dit m.a.w. nie verwerf nie, maar is daartoe geroep. Hierdie ordening gaan egter dié van die Leviete ver te bowe aangesien dit deur eedswering volgens die orde van Melchisedek geskied het. Die doel van die ordening is dat Christus as uitdelger van sondes moes optree.

Alle pogings, filologies en godsdiens-histories, om teleioun uit sy hellenistiese samehang los te maak en na 'n Palestyns-aramese oersituasie te vra, was tot dusver nie geslaag nie. Hier moet egter in die eerste plek na die invloed van die Joodse Apok. gevra word. Ook in die Apok. kom 'n soortgelyke teleioun voor. Test. (Gad 7:1). ${ }^{14}$ )

Al sou ons teleioun nie uit sy Joodshellenistiese verband kon losmaak nie, moet egter sonder twyfel aanvaar word dat die O.T. tradisie hierdie begrip help vorm het. Hier gaan dit egter bo die O.T. tradisie uit. Die voleinding en wyding van die Hoëpriester, beskryf Sy bewaring in versoeking. Sy vervulling van die priesterlike taak en Sy verhoging tot die Verlosser van die hemelse wêreld. ${ }^{15}$ ) In $2: 10$. $5: 9$ en $7: 28$ word van Christus gesê dat $\mathrm{Hy}$ deur Sy verhoging voleindig is. Hierin word enersyds tot uitdrukking gebring dat $\mathrm{Hy}$ self die Voleindigde is, en andersyds die vaardigheid verwerf het om ander mense op dieselfde wyse te voleindig. ${ }^{16}$ )

(ii) Teleioun in persoonlike kwalitatiewe betekenis.

Die vraag wat hier na vore kom is of a.g.v. die uitspraak emathen af hôn epathen in $5: 8$, aanvaar moet word dat daar 'n sedelike of morele ontwikkeling in Christus plaasgevind het, wat tot 'n etiese perfektheid gelei het deur die teleiôtheis wat Hy ervaar het. (2:9). Hierdie bewering lyk paradoksaal. Hoe

16) 0. Michel, a.w.. bls. 225 
kon Christus iets word wat Hy nie tevore was nie? Aan die een kant word Sy sondeloosheid geskets en aan die anderkant Sy volkome mensheid.

„Der Verfasser des Hebräerbriefs hat . . . den Mut aufgebraucht, wie vielleicht kein anderer Theologe der Urgemeinde in geradezu anstöszig menschlichen Ausdrücken von Jesus dem Menschen zu sprechen, obwohl gerade er vielleicht stärker alsjeder andere die Gottheit des Sohnes betont." ${ }^{17}$ ) As gevolg van hierdie volkome mensheid van Christus kan die voorstanders van hierdie „ontwikkelingsopvatting“" dus nie aanvaar dat teleiôtheis hier gesien moet word as blote bereiking van ' $n$ hoogte- of ' $n$ eindpunt nie. Om dit as materieel neutrale opvatting te sien is dan 'n onverdedigbare akstraksie.

Om hierdie rede beweer $P$. J. du Plessis ${ }^{18}$ ) dat aangesien die brief die menslikheid van Christus so sterk beklemtoon, 'n innermenslike ontwikkeling in die opvatting ingesluit moet wees. "If the true human nature of the Redeemer is equitably appreciated, it is hardly possible to exclude from this concept an element of personal development". Hy beweer verder dat die ontwikkeling van sedelike en morele vermoëns nie vorige onvolmaaktheid hoef te impliseer nie. ' $n$ Kind het volgens hom ' $n$ volkome menslike natuur selfs al is hy nog onontwikkeld. Volwassenheid bring dan die volle kapasiteite na vore. Wanneer binne die grense hiervan gesien, is ontwikkeling in Christus nie buite orde te beskou nie, meen hy, maar dan moet as doel hiervan gesien word die verlossende sending van Christus. Nie alleen die laaste deel van Sy lewe was ontwikkeling deur lyding nie, omdat Sy hele lewe gekarakteriseer kan word as 'n staande realisering van Sy sending. Hier is 'n tweeledigheid t.o.v. die betekenis van teleioun. Aan die een kant die goddelike inisiatief t.o.v. die roeping van Christus as ewige Hoëpriester. Dit word aangedui deur die kulties-sakrale karakter van die opvatting. Aan die anderkant is daar die duidelike subjektiewe verwesenliking van Sy middelaarskwaliteite in noue relasie met Sy volle Persoonlikheid, binne die perke van die menslike natuur.

17) O. Cullman, a.w., bls. 92.

18) P. J. du Plessis, a.w., bls. 216 
Nie een van die twee aspekte kan verberg word nie. ${ }^{19}$ )

Die saak in 5:9 word besleg deur kaiper wat laat verstaan dat daarin geen paradoks is om te beweer dat Christus deur lyding gehoorsaamheid geleer het nie. ${ }^{20}$ ) emathen en epathen dui nie die historiese moment aan waarin Hy kennis van gehoorsaamheid d.m.v. 'n daad van lyding opgedoen het nie. Hierdie enkele bewering dui al die ervaringe oor $S y$ hele lewe aan. Teleiôtheis is die finale stadium van Sy ontwikkeling, nie deur 'n enkele daad van gehoorsaamheid nie, maar een wat bestaan in 'n kompleksiewe ontwikkeling insluitende alle ervaringe wat karakteristiek is van die menslike natuur, waarvan lyding die mees prominente is. Deur hierdie verwesenliking het $\mathrm{Hy}$ die doel van Sy ordinering bereik, wat was om die bron te word van ewige verlossing vir almal wat Hom gehoorsaam is. ${ }^{21}$ ) Sy dood en opstanding was die finale fase van Sy volmaking. "Thus He may be said to have been perfected through a lifetime of full experience with and of human nature". ${ }^{22}$ ) Tot sovêr P. J. du Plessis.

Michel ${ }^{23}$ ) beweer dat die Christologiese motief in 5 : 9 beteken dat Jesus Christus, terwyl Hy voor God en voor die mens die regte voornemens gehad het, tot hoëpriester gewy is. Ook moet daaraan gedink word dat hier iets fundamenteels van die Deuteronomistiese leer na vore kom. "Volkome moet jy met Hom jou God wees" (Dt. 18:13). Hy meen ook dat hier iets na vore kom van die ganse gehoorsaamheid aan die Tora soos in Qumran vereis is.

Delling ${ }^{24}$ ) het aangetoon dat teleios in die sin van volkomene in etiese $s i n$ in die N.T. nie voorkom nie. Hierby sluit Strathmann ${ }^{25}$ ) aan die deur te beweer dat Christus in $5: 9$ nie voleindig word in die sin van sedelike volkomenheid nie en ook nie m.b.t. Sy verhoging nie, maar omdat $H y$ alleen op dié

19) P. J. du Plessis. a.w.. bls. 217

20) " $\quad$ " $\quad$. $\quad$. $\quad$ " 220.

21) "

22) " " " " " "

23. O. "Michel " ". ". 227.

24) D. G. Delling " $" ~ 78$.

25) H. Strathmann, Der "Brief" an die Hebräer, Göttingen 1963 bls. 100. 
wyse die doel kon bereik as Hoëpriester van almal. Teleiôtheis sê dus hiervolgens niks anders as dat die hoogtepunt bereik is nie. ${ }^{26}$ ) Van die kant van God word m.a.w. niks meer gevra nie vgl. Joh. $17: 4$ ${ }^{2 i}$ ) ,In elk geval is niet bedoeld: de afsluiting van Jesus' zedelijk-religieuse ontwikkeling tot een gerijpte persoonlijkheid." ${ }^{28}$ )

Dit is baie duidelik dat hoewel bv. deur du Plessis t.o.v. Christus gestel word dat daar nie sprake is van vorige onvolkomenheid nie, hier tog na vore kom die sedelike ontwikkeling in die menslike natuur van Christus. Dit is waar dat die Hebreërbrief meer as die ander N.T. geskrifte die volkome mensheid en vernedering van Christus beklemtoon, maar dat hier van sedelike ontwikkeling sprake kan wees, wat op 'n perfektheid uitloop wat Hy dan nie vooraf sou hê nie is te betwyfel. Ons sal verder op hierdie aangeleentheid moet ingaan.

(iii) Teleioun as volbrenging, deurvoering, verwerkliking van 'n opdrag of taak, die bereiking van 'n eskatologiese doel.

Ten eerste is dit belangrik om hier te stel dat ook in ons ondersoek van die betekenis van teleios, ons die Bybelse waarheid moet laat geld, dat ons nie oor die Persoon van Christus kan spreek los van Sy werk nie.

Die Hebreërbrief druk die werk van Christus uit in kultiese taal en terme, en maak daarby van Hellenistiese-Alexandrynse kategorië gebruik om sy verkondiging aangaande die Seun en een ware Hoëpriester oor te dra. Daar is reeds voldoende aangetoon dat in die Hebreërbrief inhoudelik niks te vind is van beinvloeding deur die Misteriegodsdiens, Gnostiek of Philoniese denke nie. Veeleer moet die O.T. en Apok. hier t.o.v. beïnvloeding in aanmerking geneem word en dan veral die eskatologiese perspektief wat deur die skrywer daaruit oorgeneem is. Wat vir ons hier van beslissende belang is, is in watter betekenis Christus self die vervulling van Sy

26) F. W. Grosheide, a.w., bls. 131

27) F. W. Grosheide, a.w., bls. 183

28) G. Stevenster. De Christologe van het Nieuwe Testament, Amsterdam 1946, bls. 263 . 
heilswerk gesien het. In Joh. 17:4 sê Christus dat Hy die werk, wat die Vader Hom gegee het, volbring het en in Joh. 19:30 verklaar $\mathrm{Hy}$ aan die kruis dat alles volbring is. Dit is duidelik dat dit in hierdie vitsprake gaan om die vervulling van die opdrag, die voltooiing van die heilswerk wat $\mathrm{Hy}$ moes volbring. Hier kom dus niks na vore van die gedagte dat wat $\mathrm{Hy}$ vò̀r die kruisiging gedoen het en wat deel van Sy heilswerk was, onvolkome of gebrekkig was nie. Met sy kruisdood het sy aardse werk die volle omvang bereik wat dit moes hê en wat alleen met die kruisdood afgesluit kon word.

Wanneer die outeur van die Hebreërbrief in 2:10 beweer dat God die Seun deur lyding voleindig het, gaan dit daarom dat die Bewerker van die eskatologiese verlossing langs hierdie weg enduit gelei is. Diá pathénôn teleiôsai). Dit is nodig om daarop te let dat die aanhaling uit Psalm 8 in Hebr. $2: 7$ nog in sy graduele sin gebruik word, maar dat in $2: 9$ brachu ti 'n temporele betekenis kry, wat duidelik die tydslinie van Christus se vernedering en verhoging aantoon. Vir die opvatting van, op die heilsweg na die telos te lei, gebruik Hebr. verskillende sinonieme bv. archégos (baanbreker), prodromos (voorloper), en aitios (oorsaak, skepper, bewerker). So word in 5:9 Christus die Bewerker van ewige saligheid genoem.

In $2: 10$ het teleioun nie die betekenis van tot sedelike volmaaktheid bring nie, asof lyding nodig was om Christus tot volkomenheid te bring nie. God het Christus langs die weg van lyding gewy tot archegos tés sôtérias. Dit het God gepas, (eprepen) dit was Sy wil. Die Seun is deur die lyding voleindig as Heilsmiddelaar. ${ }^{29}$ ) Hierdie voleindiging word bereik deur die offerdood van Christus.

Ook in 5:8-10 moet die teleiôtheis van Christus gesien word vanuit die heilshistoriese sotereologiese gesigspunt want dit sien op Jesus se heilswerk. Nadat $\mathrm{Hy}$ voleindig is d.w.s. volkome toegerus is as Heilsmiddelaar het $\mathrm{Hy}$ vir almal wat Hom gehoorsaam is die Bewerker van ewige saligheid geword. As $5: 8$ sê dat Jesus gehoorsaamheid geleer het uit

29) G. Sevenster, a.w., bls. 263 opmerking 2. 
wat $\mathrm{Hy}$ gely het, kan hieruit nie gekonkludeer word dat $\mathrm{Hy}$ ongehoorsaam was of voorheen nog nie gehoorsaamheid geleer het nie. Daar was geen grade van gehoorsaamheid by Jesus nie m.a.w. Hy was nie vòòr Sy lyding minder gehoorsaam as daarna nie. Een van die twee uitstaande aspekte van die Seunskap van Christus was juis Sy gehoorsaamheid aan die Vader, ${ }^{30}$ ) (Joh. 6:38) wat Hy nie eers deur lydinge betoon het nie, maar as kind alreeds betoon het deur in die dinge van Sy Vader te wees. (Luk. 2:49). Jesus se voleinding is afsluiting van Sy volkome gehoorsame lewe. ${ }^{31}$ ) Deur lyding het Jesus geleer wat hierdie gehoorsaamheid vir Hom alles ingehou het. $\mathrm{Om}$ in gehoorsaamheid die heilsplan van God uit te voer het lyding geverg. As Ebed Jahwe moes Hy die lydensweg enduit loop en alleen Sy volkome gehoorsaamheid het dit moontlik gemaak. Hy was gehoorsaam tot die dood toe, die dood van die kruis. (Fil. 2:8). Sonder hierdie volkome gehoorsaamheid sou Hy nie die lydensweg kon betree nie.

Die heilswerk van Christus geskied op die heilshistoriese linie wat na 'n télos beweeg. Die kruisdood is ' $n$ gebeure op hierdie linie wat ef hapax plaasgevind het en die middelpunt en hoogtepunt van die heilshandeling van God in die verlede was. ${ }^{32}$ ) So voleindig Christus Sy aardse heilswerk. Dit is Sy volbragte heilswerk.

(2) Christus se teleioun aan die gelowiges.

Hier word ons aandag geverg deur die uitsprake in $2: 11$, en $10: 14$ waar Christus as subjek van die heiliging en voleindig aangetoon word en die gelowiges as die ontvangers daarvan. Hiermee saam sal ons die uitsprake in $7: 11+19,9: 9$ en $10: 1$ onder oë moet neem aangesien dit hierin gaan om 'n teenstelling tussen die volkome werk van Christus en die wet en offers van die Ou Verbond, wat tot niks instaat was nie.

In 2: 11 beweer die outeur dat Hy wat heilig (ho hagiadzôn) en hulle wat geheilig word (hoi hagiadzomenoi) almal uit Een is. In 10:14 word aangetoon dat Christus

30) O. Cullmann, a.w., bls. 289

31) G. Sevenster, a.w.. bls. 263.

32) O. Cullmann, Christus und die Zeit, Zürich 1962 bls. 117. 
deur een offer vir ewig voleindig het (teteleiôken) diè wat geheilig word (hagiadzomenous).

Hierteenoor word in 7:11 die onvolkomenheid van die Levitiese priesterskap gestel en in 7:19 dat die wet niks kon voleindig nie (ouden eteleiôsen) terwyl in $9: 9$ aangetoon word dat die gawes en offers diè een wat die diens verrig (ton latreuonta) na die gewete nie volkome kon maak nie (teleiôsai). In 10:1 word die onmag van die wet genoem om die wat toetree tot volmaaktheid te lei (teleiôsai).

Tussen teleioun en hagiadzein bestaan ' $n$ noue teologiese en Christologiese samehang. ${ }^{33}$ ) In die Hebreërbrief word hoofsaaklik teleioun, hagiadzein en katharidzein gebruik om die heilswerk van Christus uit te druk. Ook in die afskeidsredes van Christus in die Johannes Evangelie word teleioun en hagiadzein in noue samehang gebruik. (Joh. 17 bv.) In 2:10 en 11 en 10:4 word die teleioun as ' $n$ afgehandelde saak geskets maar die hagiadzein as 'n voortgaande proses. Die offer van Christus het 'n nuwe verhouding tot God geskep en wat ' $n$ eenmalige gebeure was teteleiôken voltrek sig nou in 'n voortwerkende proses (hagiadzomenous). ${ }^{34}$ ) Hebreërs verklaar d.m.v. teteleiôken dat die sit aan die regter hand van God alreeds plaasvind, maar dat die offer bly geld vir die wat die nut ontvang van die volbragte werk van Christus. ${ }^{35}$ ) Die praes, part. hagiadzomenous dui diegene aan wat nou leef en die een na die ander die vrug ontvang van die werk van Christus.

Aangesien hagiadzein in so ' $n$ noue en onlosmaaklike samehang met teleioun voorkom, is dit vir ons ondersoek noodsaaklik om die betekenis daarvan vas te stel. Op die betekenis hiervan het S. P. J.J. van Rensburg ${ }^{36}$ ) uitvoerig ingegaan. In die eerste plek word aangetoon dat nêrens in die N.T. sprake is van die heiliging van die enkeling los van die gemeente nie. Die gemeente word in die eerste plek deur God in Christus geheilig (afgesonder) en die Heilige Gees sit hierdie heiliging voort. Alleen as lid van die gemeente, die Kerk, het die gelowige deel aan die heiliging. Dit is genadewerk wat

33) O. Michel. a.w., bls. 146.

34) 0 . Michel, a.w.. bls. 146.

35) F. W. Grosheide, a.w., bls. 234.

36) S. P. J. J. van Rensburg. Hagios in die Nieu-Testamentiese voorstelling. Pretoria 1958, bls. 424 - 434. 
aan die gelowige geskied.

Om hierdie rede moet afgewsys word:

(a) Alle vorme van indiwidualistiese, wettiese en moralistiese sélfheiliging. Dan word dit selfverlossing en ' $n$ werk van mense en is dit nie meer gawe van God nie.

(b) Elke versedeliking en vervlakking van hierdie suiwer religieuse heiligheidsvoorstelling tot 'n moralistiese begrip.

(c) Elke opvatting dat daar grade van heiligheid is.

(d) Elke perfeksionisme t.o.v. sogenaamde heiligheid.

(e) Die dwaling van die passiewe geloofsquietisme.

Uit hierdie gegewens is dit duidelik waarom ook nie t.o.v. teleioun van sedelike volmaaktheid of etiesmorele perfeksionisme sprake kan wees nie. Tussen die teleioun wat aan Christus voltrek is en dié deur Christus aan die gelowiges bestaan op hierdie punt geen verskil nie T.o.v. die gelowiges word in $2: 10$ en 10:4 aangetoon dat die teleioun reeds aan hulle voltrek is terwyl die hagiadzein voortgesit word. Indien teleioun sedelike volmaaktheid bewerkstellig het, waarom is hagiadzein dan nog nodig? Teleioun kan hier dus niks met sedelike of etiese volmaaktheid te doen hê nie. Elke moralistiese oyvatting is hier uitgesluit.

In $7: 11$ en 19; $9: 9$ en $10: 1$ word as die onmag van die wet en die gawes en offers aangedui dat hulle nie hulle doel kon bereik nie $\mathrm{nl}$. om vergewing en versoening te werk en die gelowige tot God te laat nader. Teenoor hierdie O.T. Kultus, wat nie die doel kon bereik waarvoor dit ingestel was nie, staan die offer van Jesus Christus wat eenmaal (10:10) plaasgevind het. Ef hapax was dit in historiese en sotereologiese $\sin$. Histories het dit èènmaal plaasgevind teenoor die dag vir dag en jaar na jaar van die priesterdiens. Sotereologies was dit eenmaal voldoende om die sondes weg te neem $(10: 10)$ en ewige verlossing te wees te bring $(9: 12)$

Die teleioun van die gelowiges is dat hulle deur Christus gelei is op die nuwe en lewende weg wat $\mathrm{Hy}$ deur die voorhangsel heen d.i. Sy vlees, ingewy het, en waarop elkeen met vrymoedigheid tot die heiligdom kan toetree. Nie meer enige aardse en gebrekkige priesterskap sal middelaar wees nie en ook nie deur die bloed van bokke en kalwers sal vergewing van sondes gesoek word nie, maar alleen deur die offerande van die liggaam van Christus. In Christus het 'n nuwe bedeling gekom, 'n 
Nuwe Verbond, die invoering van 'n beter hoop waardeur ons tot God nader (7:19). Nou staan die Godsvolk, die gemeente van Christus, nie meer veraf en is hulle nie meer deur die voorhangsel van die heiligdom geskei nie. Elkeen kan nou deur Christus tot God gaan. Hulle is nog sondaars, maar die vergewing van sondaars is seker deur die bloed van Jesus Christus. Dit is dan hulle teleioun.

Dit sou om hierdie rede ook onmoontlik wees om te veronderstel dat die O.T. offers tot perfeksie moes lei. Afgesien van die feit dat dit nie sonder Christus se soendood moontlik was nie, is die vraag of ons in Dt. 18:13 ' $n$ eis vir sedelike volmaaktheid of perfeksionisme moet sien. Hierin gaan dit om ' $n$ afwysing van waarsêery en goëlery en die eis dat God alleen aangehang moet word. Ons kan dus nie met du Plessis ${ }^{37}$ ) saamstem wat die doel van die O.T. offers die verkryging van sedelike perfektheid noem nie. In Christus kan ons egter nou tot God nader. $(7: 19)$.

(3) Christus as archégos kai teleiôtés tés pisteos $12: 2$

Hier word die lesers vermaan om die oog gevestig te hou op Jesus die owerste Leidsman en Voleinder van die geloof. T.o.v. hierdie uitspraak bestaan daar hoofsaaklik twee opvattings, ${ }^{38}$ ) die pedagogiese en die sotereologiese. Volgens die eerste opvatting het Jesus die geloof tot die hoogste vorm van volmaaktheid gevoer en is $\mathrm{Hy}$ slegs ' $n$ Voorbeeld by uitnemendheid en moet Hy hierin nagevolg word. Volgens die tweede opvatting word ruimte gelaat vir Jesus se persoonlike geloof, maar word Hy gesien as die "Auctor Fidei" van die gelowiges óók van die Ou Verbond.

Grässer, ${ }^{30}$ ) e.a. het daarop gewys dat hierdie uitdrukking van mitiese oorsprong is en herinner aan die verlosser en leier van die verlostes in gnostiese voorstellingskring. Christus is dan ook die eerste en laaste wat werklik geglo het. Michel, ${ }^{\text {to }}$ ) wys daarop dat hierdie uitdrukking 'n hellenistiese klank laat hoor, maar dat ons dit veeleer moet sien as uitdrukking van die O.T. heilsbeskouing, wat dikwels tot die belydenis van die gemeente be-

37) P. J. du Plessis, a.w., bls. 229.

38) P. J. du Plessis, a.w., bls. 222 - 223.

39) E. Grässer, Der Glaube im Hebräerbrief, Marbura 1965. bls. 206.

40) O. Michel, a.w., bls. 145. 
hoort het. ${ }^{41}$ )

Teleiôtés kan nie beteken dat Jesus die geloof op die trap van die hoogste voleinding verhef het nie, maar beskryf die voltooide werk vir Sy gemeente. Die besondere van Hebr. 12:2 lê daarin dat die Verlosser self in die geskiedenis op hierdie weg van die geloof voorgegaan het en dit begaanbaar gemaak het. ${ }^{42}$ )

Dit is duidelik dat teleiôtés nie van archégos losgemaak kan word nie. Die betekenis van eersgenoemde kom eers tot uiting in verbinding met laasgenoemde. Hierin kan weereens die tydslinie gesien word wat tussen die arché en die telos lê. Hierdie owerste Leidsman is nie alleen die Een wat die geloof begin het nie maar dit ook tot voleinding tot die telos gebring het. Daarom gaan dit ook nie hier om die betekenis van teleioun as, tot volmaaktheid bring nie, maar om die heilshistoriese tot voleinding te bring. Die uitdrukking di hupomonés trechômen bevestig hierdie betekenis veral as dit ook gesien word in samehang met wat Paulus sê in Phil. 3:12. Hy is nog nie volmaak (teteleiômenai) nie, maar jaag nog na die doel. Ewe bekend is die wedloop waarin die gelowige gewikkel is volgens 1 Kor. $9: 24$. Die gelowige moet so hardloop dat hy die prys sekerlik kan behaal. Die telos, die eindpunt van die wedloop is nog nie bereik nie, dit word pas eers bereik wanneer die regverdige Regter dit sal gee op die dag van Sy wederkoms 11 Tim. $4: 8$.

Ons wil nie ontken dat die skrywer van Hebreërs van hellenistiese of gnostiese uitdrukkings gebruik maak nie, maar hier kom niks van 'n ruimtelike of vertikale verlossingsbegrip na vore wat los van die tyd staan nie. Die skrywer dink eskatologies en heilshistories, die trechômen in die geloof vind op die tydslinie plaas. "Das A.T. zwingt ihn dazu, in der Spannung zwischen dem Jetzt und der Zukunft, zwischen Heilszusage und Heilserfüllung durchzuhalten"s 4 )

Het Jesus self geglo en is Hy hierin vir ons 'n voorbeeld? . . . . hij is een leidsman des geloofs ook in dit opzicht, dat hij ons zelf in een alles overwinnend geloven in God is voorgegaan" ${ }^{44}$ ) Cullman ${ }^{45}$ ) merk ook op; "dasz Jesus

41) O. Michel. a.w., bls. 434

42) O. Michel, a.w., b/s. 434.

43) O. Michel, a.w., bls. 77.

44) G. Sevenster, a.w., bls. 259 
selbzt geglaubt hat, und dasz er die Menschen zum Glauben an sein Werk gebracht hat." Dat daar by Jesus 'n onwankelbare vertroue op Sy Vader was kan nie ontken word nie, maar om die vertroue van Christus op een lyn met ons geloof te stel is seker nie verdedigbaar nie.

Ons insiens gaan dit nie hier om die vraag of Jesus self geglo het en daarom 'n voorbeeld van geloof was nie, maar om die feit dat Hy Sy heilswerk enduit gevoer en volbring het en opgrond hiervan ons geloof tot die eindpunt sal bring. Dit gaan dus nie hier om nabootsing van die perfekte geloof van Christus nie, maar om die navolging deur die geloof op die heilsweg wat Hy vir ons geopen het as Voorloper.

Ook t.o.v. hierdie uitdrukking moet ons dus konkludeer dat dit nie hier gaan om teleioun in die sin van volmaaktheid of perfektheid nie.

(4) God as Subjek van teleioun en die gelowiges as objek. In 12 : 23 word melding gemaak van die .geeste van die volmaakte regverdiges." Hier skyn dit asof God die Subjek is van die voleindiging van die regverdiges wat hier ten sprake is. In hierdie woorde breek weer die laat Joodse uitdrukkingswyse van die outeur deur. ${ }^{16}$ ) Die gestorwenes is volgens die Apok. geeste, en regverdig is hulle om hulle te onderskei van die ander.

Reeds in die Jodendom is die „,volmaakte regverdiges" na hulle dood in ' $n$ besondere wagtoestand verplaas. ${ }^{17}$ ) Hier het ons te doen met 'n transendente perspektief in die hemelse Jerusalem. Hierdie regverdiges verkeer nie hier omdat hulle sedelik volkome of perfek was nie, maar omdat hulle deur God tot die einde, die doel (telos) gebring is. ${ }^{48}$ ) Dat hierdie toestand van die regverdiges volkome 'n daad van God was druk die passief teteleiômenôn uit i.p.v. die adjektief teleioi. Hierdie regverdiges moet die gelowiges uit Christelike en vòòr Christelike tyd wees. Hulle het nou in die onmiddelike nabyheid van God gekom. ${ }^{10}$ )

45) o. Cullmann, Christologie, bls. 98.

46) 0 . Cullmann. Christologie, bls. 466

47) O. Cullmann, Christologie, bls. 467.

48) H. Strathmann, a.w.. bls. 151.

49) D. G. Delling, a.w., bls. 84 . 
(5) Teleioun in die betekenis van volheid, voltalligheid. $11: 40$

In 11 : 39 sê die skrywer dat die geloofshelde van die Ou Verbond, die belofte nog nie ontvang het nie, sodat hulle nie sonder ons voleindig sou word nie (teleiôthôsin) Hier word deur die skrywer baie duidelik gestel dat voleindiging vir die oues sou bestaan in die verkryging van die patris en die polis wat God beloof en vir hulle berei het. ${ }^{50}$ ) Die bereiking hiervan is egter nie 'n saak vir enkelinge of een of ' $n$ paar geslagte nie. Dit geld die hele Godsvolk, die gelowiges van die Oue sowel as die Nuwe Verbond. Die oues moes wag op die Christelike gemeente, die gelowiges van vandag.

Daarom kom in hierdie teks die betekenis van die plèrôma na vore soos Paulus dit in Ef. $4: 13$ uitwerk. Hierdie plérôma van Christus $\mathrm{nl}$. Sy Kerk, moet tot die volle grootte groei soos ' $n$ volwasse man. Die perfektheid van die liggaam van Christus is ook hier nie in sedelike sin nie, maar die geheelheid, die voltalligheid daarvan. ${ }^{51}$ ) Dit sluit in Jood, heiden, slaaf, vryman, man en vrou. Die saak in $11: 40$ word besleg deur die mé chôris hémôn. Die „ons" moet noodsaaklik bykom voordat die volheid bereik kan word en die patris geërf kan word. Die „ons“ is die Kerk van Christus, die volk van die nuwe bedeling.

Dit is ná bogenoemde duidelik dat teleioun hier nie met volmaak vertaal moet word nie, maar veeleer met voltallig. So sal die werklike betekenis van $11: 40$ alleen tot sy reg kan kom. Die getal moet volgemaak word, die Kerk van Christus moet die voltal word wat Hy bepaal het. Die gelowiges van die Ou Verbond moet op die bereiking hiervan wag. Deur geen sedelike volmaaktheid kan hulle hierdie plérôma voor die bestemde tyd bewerkstellig nie.

(6) Teleios in teenstelling met népios $5: 14,6: 1$.

In 5:12 word die lesers verwyt dat terwyl hulle vanweë die tyd leraars behoort te wees, weer die eerste beginsels geleer moet word. Hierdie eerste beginsels word dan vergelyk met die melk waaraan 'n kind (népios) behoefte

50) D. G. Delling, a.w., bls. 85

51) A. Richardson. An introduction to the Theoloqy of the New Testament, New York 1958, bls. 253. 
het, terwyl vaste spyse vir volwassenes teleiôn bedoel is. Die skrywer gaan in 6:1 verder deur te sê dat hy na die volmaaktheid teleiotéta wil voortgaan, sonder om hom weer te bepaal by dinge soos bekering uit dooie werke, die leer van die Doop, handoplegging ens.

Michel ${ }^{52}$ ) merk hierby op dat t.o.v. die teenstelling teleios-népios daar pararelle bestaan op Joodse en nie Joodse gebied, en dat dit die onderskeid uitdruk tussen mense in die geestelike rypheid, in wasdom en voortgang in die kennis in die ou tyd. Op Grieks-hellenistiese gebied kan die begrip van tetelesmenoi deur die inisiasieakte van die misterie-vroomheid bepaal wees. (Iren. Adv. Haer. 121, 3) d.w.s. retories of taalkundig van die misterievroomheid af bepaal wees. In sy leerlingkring kon Pithagoras tussen teleioi en népioi onderskei. Nog skerper word die onderskeid tussen teleioi en idiôtai deur die Valentiniane gemaak. Die skooltaal moes noodwendig volgens stadia, die misteries volgens teenstelling groepeer.

In hierdie teenstelling by Hebr. gaan dit nie om ' $n$ hellenistiese of gnostiese teenstelling nie, omdat hier nie sprake is van ' $n$ metafisiese teenstelling nie ${ }^{53}$ ) Geen mistiese of sakramentele ervaring word in die begrip ingelê nie. ${ }^{54}$ ) Dit gaan hier nie om 'n vaardigheid wat deur oefening bereik is nie, maar om 'n geestelike onderskeidingsvermoë.

Die kind is hier ' $n$ leerling. ${ }^{35}$ ) Die gelowiges is kinders omdat hulle in onvolwassenheid teruggeval het. Hulle is onbedrewe in 'n woord van geregtigheid. Aangesien van hulle verwag word om self onderrig te gee kan hierdie woord van geregtigheid wees "die richtige Rede". ${ }^{58}$ ) Dit gaan nie hier om 'n geheimenisleer wat net vir ingewydes bedoel is nie. Teleioi korrespondeer met didaskaloi. Hulle kan nie onderrig gee as hulle nie self tot volwassenheid ontwikkel het nie. Volgens du Plessis ${ }^{58}$ ) gaan dit egter in teleiotéta 6:1 nie om volwassenheid nie, maar om perfektheid, volmaaktheid.

52) O. Michel, a.w., bls. 226 - 227.

53) O. Michel, a.w., bls. 228.

54) O. Michel, a.w.. bls. 237.

55) P. J. du Plessis, a.w. bls. 206

56) O. Michel, a.w., bls. 65.

58) P. J. du Plessis, a.w., bls. 209. 
Wanneer iemand die volle omvang van die geestelike volwassenheid bereik het en in hierdie opsig teleios is (5:14), kan hy onderrig word aangaande die teleiotés $(6: 1)$.Teleiotés moet hier nie gesien word as enigiets behalwe die volle omvang van die leer wat die skrywer aan die lesers bekend wil maak. Dit gaan hier dus ook nie om 'n leerstuk waarmee sedelike volkomenheid meegedeel sal word nie, maar om die verkonding van die volle betekenis van die heilswerk van Christus.

(7) Telos as eskatologiese doel. $3: 6,14 ; 6: 11 ; 7: 3 ; 9: 26$.

Die begrip telos as eskatologiese doel kom ook baie duidelik na vore in bogenoemde tekste. In 3:6 gaan dit om die roem van die hoop wat tot die einde toe mechri telous bebaian vasgehou moet word, terwyl in 3:14 die begin van die vertroue vasgehou moet word tot die einde toe. In $6: 11$ word vereis dat daar gekom moet word tot die volle sekerheid van die hoop tot die einde toe achri telous. In $7: 3$ word van Melchisedek gesê dat hy sonder lewenseinde was méte Zôés telos en in $9: 26$ noem die skrywer die tyd, waarin Christus verskyn het, die voleinding van die eeue (sunteleia tôn aiônôn).

In al hierdie uitdrukkings kom duidelik na vore die eskatologiese denkkategorie van die skrywer van die brief. Alles loop vir hom na 'n doel toe, na 'n eindbestemming waarin die vervulling, die afsluiting en verwerkliking sal plaasvind van dit wat nou in volle gang is. Hierby sluit 1 Petr. $1: 13$ aan deur die eis dat volkome gehoop moet word op die genade (charis) wat op die punt staan om aangebied te word. Teleiôs kan hier in graduele en temporele sin opgevat word. In sy verband gesien is laasgenoemde die waarskynlikste. Die wederkoms kan enige oomblik aanbreek. Omdat die telos nou naby is moet enduit (teleiôs) geloop word.

Hierdie charis waarop gehoop moet word is die sôtéria die eskatologiese heil wat op die punt staan om met die wederkoms van Christus aan te breek. Die skrywer van die Hebreërbrief roep op tot hierdie hoop in $3: 6,14$ en $6: 11$, die hoop tot die einde toe, totdat die telos, die eskatologiese voleinding aangebreek het.

\section{E. GEVOLGTREKKINGS.}

Ons het aan die begin van hierdie ondersoek as motief gestel dat ons wou vasstel of die betekenis van teleios en sy derivate in 
die Hebreërbrief slegs:

(a) kulties-sakraal opgevat moet word of

(b) moralisties, perfeksionisties of

(c) heilshistories-eskatologies.

Ons het aangetoon dat in die Hebreërbrief, hoewel van hellenistiese en kultiese terme en uitdrukkings gebruik gemaak word, nie sprake is van teleioun as 'n formele wydings- of inisiasie begrip nie. Hierin kom niks voor van 'n ruimtelike skema nie. „diesseits" en "jenseits" soos in die Aleksandrynse denke nie. Die eskatologiese motief oorheers self waar van ruimte uitdrukkings gebruik gemaak word.

Ons het ook probeer aantoon dat in hierdie begrip nie 'n inhoud gelê kan word van 'n sedelike-morele perfeksionisme nie. Dit is wel waar dat Hebreërs die volkome mensheid van Christus baie sterk beklemtoon en dat op grond hiervan 'n sekere ontwikkeling in Sy menslike natuur aanvaar moet word. Daar bestaan egter geen aanduiding in Hebreërs of in die res van die N.T. dat Christus sedelik ontwikkel het of in gehoorsaamheid toegeneem het nie. Ons kan dus nie aanvaar dat toe God aan Christus die teleioun voltrek het, $\mathrm{Hy}$ iets geword het wat $\mathrm{Hy}$ nie tevore was nie. Christus het Homself gesien as die Uitvoerder van die heilsplan van God en die Bewerker van die saligheid van die mensheid. Op hierdie weg wat van begin tot einde lydensweg was het $\mathrm{Hy}$ met volkome gehoorsaamheid gegaan. Hy het die politieke Messiasrol afgewys wetende dat $\mathrm{Hy}$ as die Ebed Jahwe vir ander plaasvervangend moet ly en sterf. Hierdie kruisweg het $\mathrm{Hy}$ tot die einde toe geloop en Sy werk volbring en tot 'n einde gevoer.

Om hierdie rede en uit wat ons uit die Christologiese motiewe van Hebreërs verstaan moet elke moralisme t.o.v. die begrip telios afgewys word sowel wat Christus betref as die gelowiges. So weinig as wat daar so-iets as selfheiliging van die gelowiges bestaan, so onaanvaarbaar is die gedagte van selfvolmaking. Heiliging en voleindiging is God se werk in Christus deur die Heilige Gees. Soos met heiliging, is voleindiging van mense nie 'n hebbelikheid waaroor mense indiwidueel en vry beskik nie, maar 'n heilsgawe van God aan Sy gemeente, wat deur Hom na Sy welbehae geskenk word. Juis wanneer ons oor "volmaking" of "volmaaktheid" in selfgenoegsaamheid en eiegeregtigheid spreek, verloor ons dit, omdat ons 'n werk en gawe van God nie tot voorwerp van eie roem of prestasie kan maak nie. 
Gods werk is nie tydloos nie, maar heilshistories met 'n eskatologiese eindpunt. Hierdie heilslinie kom in die Hebreërbrief baie sterk na vore en oorheers elke ander motief. Die gister, vandag en môre ef hapax, eis to diénekes en ek deuteron gee volkome die linie weer waarop die skrywer die werk van Christus sien $\mathrm{nl}$. Sy aardse, teenwoordige en eskatologiese werk. Ook hier kom die spanning na vore van reeds vervul en nog nie voleindig. Die spanning van die hede wat op die heilslinie lê tussen Christus se eenmalige offer en Sy wederkoms. Nou tree Hy vir ons in as Hoëpriester en sal ons met Sy koms tot die einde voer.

Ons moet toegee dat met hierdie ondersoek sekerlik nie die laaste woord oor hierdie probleem rondom teleios in die Hebreërbrief gespreek is nie. Dit was slegs ' $n$ poging om te help antwoord gee op die vraag na die presiese betekenis daarvan. Die betekenis wat ons daaraan geheg het is nie die populêre nie en sal seker onderhewig wees aan baie kritiek soos trouens al gebeur het t.o.v. hierdie opvatting. 